\title{
Land trusts and beginning farmers' access to land: Exploring the relationships in coastal California
}

\author{
Jessica Beckett ${ }^{2}$ and Ryan E. Galt ${ }^{b}$ \\ University of California, Davis
}

Submitted May 21, 2013 / Revised October 8 and December 15, 2013 / Accepted January 3, 2014 / Published online March 13, 2014

Citation: Beckett, J., \& Galt, R. E. (2014). Land trusts and beginning farmers' access to land: Exploring the

relationships in coastal California. Journal of Agriculture, Food Systems, and Community Development, 4(2), 19-35.

http://dx.doi.org/10.5304/jafscd.2014.042.008

Copyright (C) 2014 by New Leaf Associates, Inc.

\begin{abstract}
This paper examines relationships between beginner farmers and land trusts in coastal California. Set within the context of land consolidation in agriculture and increasing land values, some beginner farmers have created innovative land tenure relationships with land trusts in order to gain access to affordable farmland. To examine the relationships between land trusts and beginning farmers, we ask: how do conservation land trusts and agricultural land trusts view their mission in relation the intersection of conservation and agriculture? Findings suggest there is a spectrum of positions that conservation and agricultural land trusts have taken in regards to the coexistence of agriculture and conservation on their land. The increasingly popular concepts found within the local food movement may be

a M.Sc. Community Development, University of California, Davis.

b Associate Professor, Department of Human Ecology \& Agricultural Sustainability Institute, University of California, Davis; 1309 Hart Hall, One Shields Avenue; Davis, California 95616 USA; regalt@ucdavis.edu

* Corresponding author: Jessica Beckett, P.O. Box 1114, Santa Cruz, California 95061 USA; +1-831-207-6255;

jbeckett@ucdavis.edu
\end{abstract}

influencing a shift in the portrayal of land trust position and mission. However, differences between how land trusts act internally and how they portray themselves publicly emerged in farmer interviews. While there may be great deal of potential for land trusts to work with beginner farmers and thereby connect a new swath of the public to conservation through agriculture, both land trusts and beginner farmers need to wade carefully into relatively uncharted waters.

\section{Keywords}

beginner farmers, conservation, land access, land trusts, local food

\section{Introduction}

It's not farmland without farmers.

- popular American Farmland Trust bumper sticker

Typically adorning older and often dusty trucks, this bumper sticker's poignancy, and indeed immediate relevance, is often lost on the casual observer. But to the owner of the truck, and to an increasing number in the food and farming sector, that short phrase symbolizes a growing reality for farmland in the United States. The average age of the American farmer has increased by one year or 
more for every census period since 1978 (Allen \& Harris, 2005). Currently the average age for farmers nationally and for farmers in California, the focus of this paper, are roughly the same, at 55.3 and 55 years of age, respectively (Allen \& Harris, 2005; Johnson, 2008).

In response to this trend, narratives gravitate toward what appears to be a beginner farmer ${ }^{1}$ movement riding the coattails of broad interest in the food system and its sustainability (Burros, 2009; Greene, Dimitri, Lin, McBride, Oberholtzer, \& Smith, 2009; Kingsolver, 2007; Martinez et al., 2010; Pollan, 2006). This surge of interest in creating rural, and even urban, livelihoods through sustainable agriculture and community food systems is composed of people of varied backgrounds (Raftery, 2011; Stern \& Nochi, 2009). "Like all farm operators, most beginning principle farm operators are White, non-Hispanic, and male. Beginning farmers, however, are more likely than established farmers to be female, non-White, or Hispanic" (Ahearn \& Newton, 2009, p. 7). By choosing to farm, many forgo higher salaries and stable incomes in favor of agricultural work that more accurately matches their credos (Galt, 2013). This current group of beginning farmers may have the potential to slow or reverse the population trend of aging farmers.

This paper examines recently established relationships between beginner farmers and land trusts, which could be an important avenue for beginner farmers' access to land. Much of the literature on beginner farmers in the U.S. focuses on how new programs need to support this new generation of farmers (Baker, Duffy, \& Lamberti, 2004; Kirschenmann, 2009; USDA, 2010), and a great deal of new curriculum has been developed across the country to prepare students for professions in sustainable agriculture and food systems (Galt, Clark, \& Parr, 2012; Jacobsen et al., 2012; Perez, Parr, \& Beckett, 2010. The national surge of interest in farming in the last decade has been hailed as a beginner farmer movement in popular

\footnotetext{
${ }^{1}$ The United States Department of Agriculture (USDA) defines a beginner farmer as someone who "has not operated a farm or ranch, or who has operated a farm or ranch for not more than 10 consecutive years" (Buland, 2010).
}

literature, one that may stem the tide of aging farmers (Bradbury, von Tscharner Fleming, \& Manolo, 2012; Raftery, 2011). However, critical research that investigates the sustainability, possibilities, directions, and structural underpinnings (or lack thereof) of this beginning farmer movement has been scant. Such research is necessary if we are to ascertain if this movement can create a longterm shift in the farming population, or whether it might fade as this new generation finds the monetary (and other) return of farming inadequate for their aspirations due to the important structural constraints discussed below.

We find it useful to contextualize the beginner farmer population within the broader agricultural and economic landscape. The aging farmer population is a symptom of rural depopulation connected to the rise of larger, mechanized farming operations. The last century saw a steady depopulation of the rural landscape in the U.S. (Berry, 1995; Gardner, 1974). In 1900 those employed directly in agricultural production made up 41 percent of the population, and, as is often noted, today that percentage has dwindled to 2 percent (Dimitri, Effland, \& Conklin, 2005; Environmental Protection Agency [EPA], 2011). This rural depopulation has been driven by the technical changes leading to higher efficiencies per input of labor - spurred largely by competition in agriculture - as well as deliberate policy ${ }^{2}$ aimed at

\footnotetext{
${ }^{2}$ In the 1960s, neoclassical economists at the Committee for Economic Development (CED), a Wall Street think tank, decided that the social allocation of labor and capital in agriculture was excessive and these labor resources could make more money if directed to other sectors of the economy (Levins, 2000; Lyson, 2004; Meter, 2012). They prompted changes in policy - the U.S. offered "public tax incentives for adopting new technology that replaced labor" (Meter, 2012, p. 3). At the same time, the grain giant Cargill was pushing to change U.S. farm policy away from the production controls that had been in place since the Great Depression and had helped keep farm incomes high even in times of overproduction, which had been plaguing U.S. agriculture for decades (Levins 2000). Cargill finally got its way in 1973 with the Nixon Administration and Secretary of Agriculture Butz, and the current subsidy program in the U.S. was born. Our "cheap food policy" is a concerted effort to boost production and keep commodity prices low, which reduces market returns to farmers while helping them with subsidies for some goods, but makes certain foods less expensive for the consuming public.
} 
reducing the number of farmers in the U.S.

The workings of agrarian capitalism, often sped up by governmental policies, have resulted in declining returns to farms in the U.S. Net farm income - total cash receipts from selling farm products, minus production expenses used to produce them, to all farms in the country dropped considerably, from US\$50 billion in 1910 (adjusted to 1988 dollars) to US $\$ 38$ billion in 1988 (Johnson, 1990, p. 5). More recently, net farm income dropped nine percent from US $\$ 46$ billion in 1962 (adjusted to 2011 dollars) to US $\$ 42$ billion in 2011 (Meter, 2012, p. 4). Farmers are more productive than ever, especially on a per-farmer basis, yet their overall return from the consumers' money spent on food has gone down, on both centennial and decadal scales. Since farmers often try to make a living on farm income, it is not surprising that we have fewer farmers, given that the farming population as a whole is chasing fewer and fewer potential net income dollars.

Over the last four decades the agricultural input and broader food industry, including most recently retailers, have become extraordinarily powerful in the food system, and have used this power to extract more surplus from the farm sector while giving it lower returns (Levins, 2000; Lyson, 2004). Throughout these changes, the power of these actors who squeeze farmers from both sides could have been challenged through U.S. anti-trust laws due to high levels of market concentration (Levins 2000), yet there has been little political will to do so. In all, then, declining net returns to the farm sector, and the farmer selfexploitation and farmworker exploitation that occurs within it, is largely deliberate, a set of choices made at the level of U.S. policy.

As is often the case, public discussion largely ignores these structural and social trends facing

In the language of economists this is "a classic case of public intervention magnifying market failure" (Meter, 2012, p. 4). In short, "our public policy has been to remove the farm labor force under the guise of economic efficiency. As the CED had hoped, both labor and capital were extracted from the U.S. farm economy (CED, 1974)" (Meter, 2012, p. 3). For Berry (1977), this is part of the larger picture that is the Unsettling of America. agriculture, instead framing "the problem" as an aging farm population, rather than seeing it as a symptom of these larger issues. We need new farmers, but throwing beginner farmers into the U.S. agricultural system, where the deck is stacked against farmers, especially small farmers, and pretending that it is a system in which they can thrive if they just work hard and smart enough, is not fair. Research on beginning farmers needs to keep these constraints in mind since they have important implications for beginning farmers.

One manifestation of these structural constraints is that the beginner farmer population is having difficulty accessing affordable farmland (Ahearn \& Newton, 2009; Gillespie \& Johnson, 2010). This means that subsidized access to land at a level below going market value — is important for many beginner farmers since returns to farms are often quite low, they often have little capital and equity in their farms, and many are trying to farm near urban areas where land prices are high. Having an economy where goods sold by the agricultural sector are consistently undervalued relative to other sectors of the economy contributes to the economic returns to land from agriculture being much less than "developed" uses (housing, shopping malls, etc.). The higher potential returns from these non-agricultural uses are rolled into land values around urban areas (Chicoine, 1981; Livanis, Moss, \& Breneman, 2006). This makes farming on the fringe more expensive, even though from a planning perspective it makes a great deal of sense for farms to exist near urban areas in terms of social engagement in agricultural literacy, as well as environmental benefits such as undeveloped watersheds and wildlife habitat (Unger \& Lyddan, 2011) and reduced emissions from transportation that contribute to climate change and urban air pollution (Brillinger, Merrill, \& Lyddan, 2013). Across larger scales, regional land values and land losses to development are very high in areas where settlement and urban development is in high demand. Every year, California loses 40,000 acres (16,187 hectares) of farmland to the spread of urban, suburban, and exurban areas (Thompson, 2009). In these regions of high demand, buying farmland can be prohibitively expensive for farmers, especially beginning 
farmers who might have very little money saved. Renting is a possibility, but without a proven track record, many landlords are hesitant to rent to beginner farmers. Renting also means farmers generally lack long-term land tenure, making it difficult for them to plan for the future.

One area where high land values, pressures from development, and a burgeoning crop of beginner farmers collide is the Central Coast of California, which is our geographic focus here. With its numerous farmer incubator programs, local food movement with 1960s countercultural roots, and accommodating year-round growing season, the Central Coast has become a hub for the beginner farmer movement, supported in large part by the growth in organic and local agriculture in the region (Guthman, 2004). However, the prospect of buying land in the Central Coast, and indeed in the rest of coastal California, is beyond the capacity of all but a few beginning farming operations. Reggie Knox, a long-time beginner farmer advocate with California Farmlink, suggested that most beginning farmers struggle to find land that includes the housing and basic infrastructure necessary to create a profitable business. With agricultural land values "substantially higher...than those in the rest of the country" (Guthman, 2004, p. 84) and situated at the forefront of the beginner farmer and local food movements, beginner farmers in the Central Coast provide an example of what beginner farmers face in locales with high land values.

Below we focus on the provisioning of land to beginning farmers through the channel of land trusts in California. With their conservation mandate, land trusts may hold a great deal of potential for meeting the land needs of the beginner farmer population, especially in areas where land values are high, such as the West and East coasts.

Through interviews with the staff of land trusts and beginner farmers who access their land, we examine the extent to which land trusts operating on the California coast are using their conservation mandate to protect farmland, the extent to which their protection encourages agricultural use of the land, and the ways in which they interact with the beginning farmer population.

\section{Land Trusts as Land Managers}

In order to access land, many beginning farmers have begun to pursue alternative land-tenure agreements with nontraditional landlords who appreciate the environmental and social goods that new, especially small-scale, direct market-oriented, organic farming operations promise. Popular news media have made much of farmers who have taken over abandoned lots in cities (Baume, 2012), leased from hospitals (Grobe, 2009), and farmed in state parks (Spencer \& Kaplan, 2010). In addition to these and other routes of land access, beginner farmers have also made agreements with land trusts. Here we focus exclusively on beginner farmer relationships with land trusts in California.

The application of trust principles to land has a long history, and the presence of land trusts in the US is immense. ${ }^{3}$ Land trusts are private landmanagement entities. In California, land trusts are vested by the state with the authority to enact some of the land conservation responsibilities of the state under the California public resource code. According to the website of the California Council of Land Trusts, land trusts in California "share a common vision for protecting the best of California - natural areas, farmlands, parks, and clean water and air" California Council of Land Trusts, 2010, para. 1). As nonprofit, 501(c)(3) tax-exempt entities, land trusts are responsible for conserving land either through fee simple ownership ${ }^{4}$ or

\footnotetext{
3 “Currently, about 145 million acres [58,679,400 hectares] of land granted for schools or similar institutional purposes are managed under a trust mandate by 22 states [which] puts the state trust approach to property squarely into the family of major public land ownership and management regimes: the much discussed National Park Service manages a mere 80 million acres [32,374,850 hectares]" (Souder \& Fairfax, 2000). Ballot measures for allocating public funding for managing these lands have passed in nearly all 50 states from 1988 to 2005 , and " $[t]$ hese ballot measures have led to the allocation of [US] $\$ 42.6$ billion of public funds to protect natural areas and farmland [through land trusts]" (The Trust for Public Land, 2006, cited in Morris, 2008). This has helped to reinforce the notion that " $[\mathrm{t}]$ he system of public ownership and management of land held in trust is arguably the oldest of all federal programs, and it is the most durable national approach to public resource ownership" (Souder \& Fairfax 2000, p. 89). ${ }^{4}$ Fee simple ownership refers to those lands that land trusts own outright, either through purchase or gift. Purchases of fee titles are supported either by the land trusts membership,
} 
conservation easements ${ }^{5}$ on properties. In California, the state with the largest number of private land trusts (Morris, 2008), land trusts manage over 200,000 acres $(80,937$ hectares) of farmland (Thompson, 2009). Thus there is a possible confluence of interests between conservation and agriculture in California that might make land trusts important actors in supporting beginner farmers in the state.

Land trusts are part of what Salamon (2002) terms the "new governance." In the new governance, the outsourced management of state responsibility is supposed to trim the size of the state, reduce the burden of mission enactment, and save money. ${ }^{6}$ However, around land trusts specifically, some have argued that "removing regulatory power from public to private jeopardizes democratic land-use planning" (Johnson, 2008, p. 23) and may "tend to ignore the interconnectivity of landscapes and the important public interest in the ecological values housed on private lands" (Morris, 2008, pg. 1223). Supporters of this new type of governance argue that any loss of democratic governance is overruled by the monetary gain. By vesting responsibility in nonprofit organizations supported by grant funding and dues-paying members, they argue, the state spends less for the same conservation outcomes. Supporters also claim that local land trusts have the advantage of familiarity with the local area, have greater success at negotiating transactions below fair market value,

grants, gifts, or by state funding through bond measure and propositions.

${ }^{5}$ Conservation easements restrict the development and use of a particular property through the creation of a secondary title or "easement" on a property. They are voluntary agreements placed on property by private owners. The easements are either sold or gifted to land trusts and remain with the parcel of land in perpetuity, regardless of whether the land ownership changes hands. The land trust as easement holder then is responsible for the enforcement of the conservation plan put forth by the easement. Private landowners can enjoy a range of benefits that act as incentives to create easements. For example, if the easement restrictions lower the fair market value of the property (which is most often the case), in many states the owner will pay a lower property tax in line with the reduced market value.

${ }^{6}$ This is prime example of Peck and Tickell's (2002) "roll-out" neoliberalism (Morris, 2008). and may better work with farmers since many farmers may prefer not to deal with government agencies (Coppock \& Ames, 1989).

Primary goals of land trusts in California, according to the California Council of Land Trusts, include protecting farmscapes, working lands, and rural livelihoods. Though they share these and other common broad goals, there are essentially two major categories of land trusts: "conservation land trusts" that are conservation-oriented, with a focus on preserving land for open space and habitat protection, ${ }^{7}$ and "agricultural land trusts" that focus on the preservation of land for agriculture (Merenlender, Huntsinger, Guthey, \& Fairfax, 2004). Both use the same long-term techniques to acquire and protect land, which most often are fee simple acquisitions and conservation easements (Coppock \& Ames,1989).

In order to carry out their missions, land trusts are supported by the public in many ways in California. The public, through the state, vests the power to conserve land in land trusts. The public supports these measures by allowing land trusts to enjoy a tax-exempt, nonprofit status, Williamson Act privileges, ${ }^{8}$ and monies from public bond measures, propositions, easement subsidies, as well as grants from state agencies such as the Coastal Commission and the Department of Conservation. As nonprofit charitable organizations, most land trusts also enjoy a "welfare exemption" on their fee simple properties, which means they are exempt from paying California property tax, except in cases when they benefit economically from the property ${ }^{9}$ (Endicott, 1993).

To examine the relationships between land

\footnotetext{
${ }^{7}$ Land trusts have had a long history of identifying with the conservation movement that birthed the national park system and the Sierra Club (Brewer, 2003).

8 The Williamson Act, or the California Land Conservation Act of 1965, is a tax relief program that lowers property taxes on agricultural and open space land if owners agree not to develop the land for 10 years. Enrolling land under the Williamson Act is considered a short-term voluntary act of preservation and greatly augments the land held in conservation by private, nonprofit, and state entities.

${ }^{9}$ Welfare exemptions can be given to any nonprofit organization that is organized for religious, charitable, hospital, or scientific ends. They were authorized by section 214 of the California Revenue and Taxation Code in 1944.
} 
trusts and beginning farmers, we ask: how do conservation land trusts and agricultural land trusts view their mission in relation to conservation and agriculture, including the role that agriculture plays in conservation? Is this changing with an invigorated public discourse around community food systems? And how do the experiences of beginner farmers working with land trusts in the Central Coast of California articulate with land trusts' messages about the possibility for agriculture and conservation to be mutually beneficial? Answering these questions will help demonstrate land trusts' potential role in helping a new generation of farmers be successful.

\section{Study Site and Methods}

The research reported in this paper began with consultations conducted during 2010-2011 with farming and land conservation stakeholders in California's Central Coast counties of Santa Cruz, San Mateo, San Benito, and Monterey. Interviews were used to elicit possible avenues of research that would be of use to this community. The results of these consultations revealed a rift between beginner farmers and land trusts in relation to their respective ideas around land use and access. It was the investigation of this rift that inspired the research on which this paper is based. From these initial conversations the research questions stated above were developed.

The data in this study come from samples of two primary populations: staff from land trusts operating throughout coastal California (from Humboldt County to San Diego County), and a group of beginning farmers working with land trusts in the Central Coast (Monterey, Santa Cruz, San Mateo, San Benito Counties). We chose to interview land trusts throughout coastal California to understand the population as a whole, and to see if the location of the land trust affected the staffs' perspective of agriculture (though this is not the focus of our analysis below). Only beginner farmers in the Central Coast were interviewed since there were no land trusts north of Marin County or south of San Luis Obispo County that were working with beginner farmers. Land trusts working with beginning farmers were most common in Monterey, Santa Cruz, and San Mateo counties, where the interviews with beginning farmers were conducted.

A list of 28 land trusts operating in coastal California was gathered from the website of the California Council of Land Trusts, and each of these land trusts was contacted. ${ }^{10}$ Of the initial 28 land trusts assumed to be in operation in the coastal counties of California, 20 responded. Of these, four chose not to participate (most cited staff time restrictions), and thus the total sample size of land trusts for the study is 16 . Of these 16 land trusts, two were agricultural land trusts, organizations with missions focused on the protection of agricultural land through land conservation. The other 14 were conservation land trusts, with missions more focused on nature preservation. In the fall of 2010 and spring of 2011 phone interviews were conducted with conservation managers, assistant directors, and/or executive directors of 15 land trusts; one interview was held in person. ${ }^{11}$ In one case, two interviews were held with personnel from one land trust; this is explained at length further on in the paper. During the land trust interviews, notes were transcribed on a computer.

We followed the USDA definition of a beginner farmer as someone who "has not operated a farm or ranch, or who has operated a farm or ranch for not more than 10 consecutive years" (Buland, 2010). The population of beginning farmers accessing land through land trusts was sampled using a snowball approach, beginning with the suggestions of the stakeholder community in the four Central Coast counties that helped shape the research questions, and branching outward. Land trust employees we interviewed also suggested farmers to contact for interviews. Seven beginner farmers ${ }^{12}$ were interviewed in person

\footnotetext{
${ }^{10}$ All were contacted in November 2010 with a personalized email. If there was no response by January 2011, they were contacted by email again. If there was no response via email by February 2011, their office was contacted via phone.

${ }^{11}$ One out-of-state land trust was also contacted and interviewed to give a national perspective on land trust attitudes and perspectives. These data were not included in this analysis.

12 In hindsight, interviewing a group of more advanced farmers in addition to this beginner farmer population would have given us more context to understand the specific qualms of the beginner farmer population in relation to land trusts.
} 
between November 2010 and March 2011. This sample of seven beginning farmers is out of a total population of 10 beginner farmers who were actively leasing from land trusts in Monterey, Santa Cruz, San Mateo, and San Benito counties during this period. The beginner farmers interviewed were all currently leasing land from land trusts or had leased land from land trusts within the past two growing seasons. Of the seven interviewees, four held additional leases on privately owned land. All interviews were recorded and subsequently transcribed.

The practice of grounded theory was central to the conception, execution, and analysis of this project. In keeping with grounded theory, according to Corbin and Strauss (1990), "the analysis [began] as soon as the first bit of data [was] collected" (p. 6. The interviews with stakeholders influenced the formulation of the questions that we would later ask the interviewees. Using concepts as the basic units of analysis, we coded data from transcriptions and notes from both land trusts and beginner farmers. During coding, we noted common themes, patterns, and deviations. Coding for the land trust interviews focused on the ways in which land trust employees specified their mission and goals, especially vis-à-vis the relationships between agriculture and conservation. Coding for the beginner farmer interviews focused on their working history, perception of land trust position and the public portrayal of their missions, and views of their land leases and the land trust's management as landlords.

\section{Findings}

\section{Land Trust Orientations Toward Conservation and Agriculture}

Land trusts in the sample varied significantly in the amount and type of land they managed. The smallest land trust surveyed oversaw 300 acres (121 hectares), and the largest ones managed acreage in the tens of thousands. As previously mentioned, there were two major categories of land trusts in the sample; the principle category we call "conservation land trusts," that is, land trusts that preserve land more generally for open space and natural resource conservation $(\mathrm{n}=14)$, and
Figure 1. Number of Conservation Land Trusts and Agricultural Land Trusts in This Study

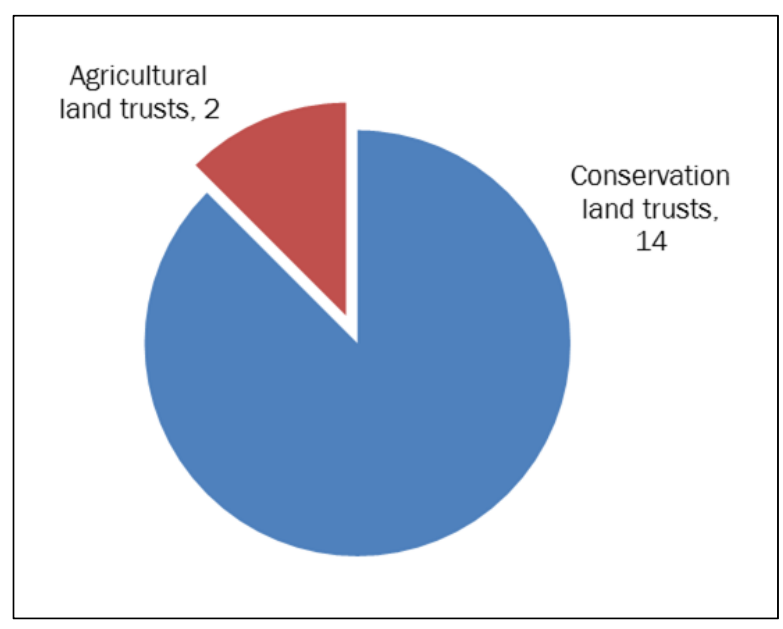

"agricultural land trusts" that are specifically oriented toward the preservation of land for agriculture $(\mathrm{n}=2)$ (figure 1). At the time of this paper, there were 173 land trusts in total in California, and of those, 15 were specifically agricultural land trusts. Agricultural land trusts were defined in the research as organizations that explicitly sought to preserve active farming rather than merely farmland. Conservation land trusts in the study often sought to preserve farmland but in no cases specified having active farming businesses as their end goal. Both types of land trusts were represented in the study and will be distinguished by type in the analysis.

As demonstrated in table 1, a large portion (10 out of 16) of the land trusts interviewed manage some form of agricultural land. Of these 10, eight are conservation land trusts. The other two land trusts that manage agricultural land are agricultural land trusts. Regardless of the type of land trust and exactly how much agricultural land the organization managed, every organization's staff had a position about agriculture and how it should or should not be integrated into the conservation mission of their particular land trust. The central interview question used to distinguish these values was, "What are the benefits and costs of agricultural agreements to your land trust?" The diversity and frequency of response are illustrated below in figure 2. Eight conservation land trusts and both agricultural land trusts answered this 
question and are included in the analysis below.

Through coding the responses, we identified six primary themes for land trusts' answers to this question: agriculture is detrimental to conservation, rural livelihoods and family farmers are important, farmers should be valued as stewards of nature, agroecological conservation is a primary focus, green jobs are key, and local food systems are important. Each of the eight conservation land trusts that answered the question responded with one definitive answer, with the exception of two organizations who gave more nuanced responses. One of these land trusts was remarkable as the two interviewees gave nearly opposite responses to the same question. ${ }^{13}$ In contrast to the relatively simple answers of the conservation land trusts, the two agricultural land trusts that answered this question each had complex responses that drew on three different themes, showing even greater nuance to how their organization viewed agriculture and conservation. These organizations' perspectives are shown graphically in figure 2 .

That agriculture is detrimental to conservation was the stance of two conservation land trusts' staff who saw no room for the coexistence of agriculture and conservation within their organization. One of these land trusts was located close to

\footnotetext{
${ }^{13}$ At this conservation land trust, there were two people interviewed, and they held divergent opinions about how their land trust operated. In all other cases of conservation land trusts in which multiple employees were interviewed, staff identified the missions and values similarly.
}

Land in any use

Land in agriculture

\begin{tabular}{crrr}
\multicolumn{2}{c}{ Land trust Fee simple } & Easement & Total \\
\hline A & 131 & 12,000 & 12,131 \\
B & 1,300 & 0 & 1,300 \\
C & $-*$ & - & - \\
D & 100 & 200 & 300 \\
E & 2,600 & 3,600 & 5,200 \\
F & - & - & - \\
G & 0 & 5,000 & 5,000 \\
H & 0 & 22,000 & 22,000 \\
I & 5,000 & 12,000 & 17,000 \\
J & 12,500 & 2,500 & 15,000 \\
K & - & - & - \\
L & 0 & 42,000 & 42,000 \\
M & 1,600 & 120 & 1,720 \\
N & - & - & - \\
O & 3,200 & 1,600 & 4,800 \\
P & - & - & - \\
\hline Average & 2,403 & 9,184 & 11,496 \\
\hline
\end{tabular}

\begin{tabular}{ccr}
\multicolumn{3}{c}{ Land in agriculture } \\
Fee simple & Easement & \multicolumn{1}{c}{ Total } \\
\hline $100 \%$ & $100 \%$ & 12,131 \\
$50 \%$ & - & 650 \\
- & - & - \\
$0.2 \%$ & - & 6 \\
$2 \%$ & $4 \%$ & 312 \\
- & - & - \\
- & - & - \\
$0 \%$ & $80 \%$ & 17,600 \\
$100 \%$ & $100 \%$ & 17,000 \\
$15 \%$ & $85 \%$ & 15,000 \\
- & - & - \\
- & $100 \%$ & 42,000 \\
$100 \%$ & $100 \%$ & 1,720 \\
- & - & - \\
$90 \%$ & $90 \%$ & 4,320 \\
- & - & - \\
\hline $37 \%$ & $44 \%$ & 11,074 \\
\hline
\end{tabular}

a Because the land trust community is rather small and intimate and confidentiality was promised, this table excludes identifying information of which organizations operate in the Central Coast, which organizations are agricultural land trusts, and other details. For the same reason in subsequent sections we do not reveal key characteristics of land trusts that could allow them to be identified.

an urban metropolis, and the staff from this land trust stated, "We wouldn't seek to preserve or encourage agriculture. We want to preserve habitat for rare species." The staff member who responded for the other land trust felt similarly, although this was a conservation land trust that managed many agricultural parcels via fee simple arrangements and easements. This staff member responded in confidence that any of the organization's public moves to appear to support agriculture was "lip service." He stated that "the organization wants to look like they are preserving agriculture so that people will give to them and allow them to get more open space."

Responses related to valuing rural livelihoods and farmers as important stewards came from the two agricultural land trusts and three conservation land trusts. The agricultural land trusts felt that rural livelihoods and family farmers were both part of supporting a functioning agricultural economy and therefore landscape. The conservation land trusts felt that rural livelihoods and family farmers were part of supporting good conservation. One 
Figure 2. Land Trust Identity in Terms of Agriculture and Conservation

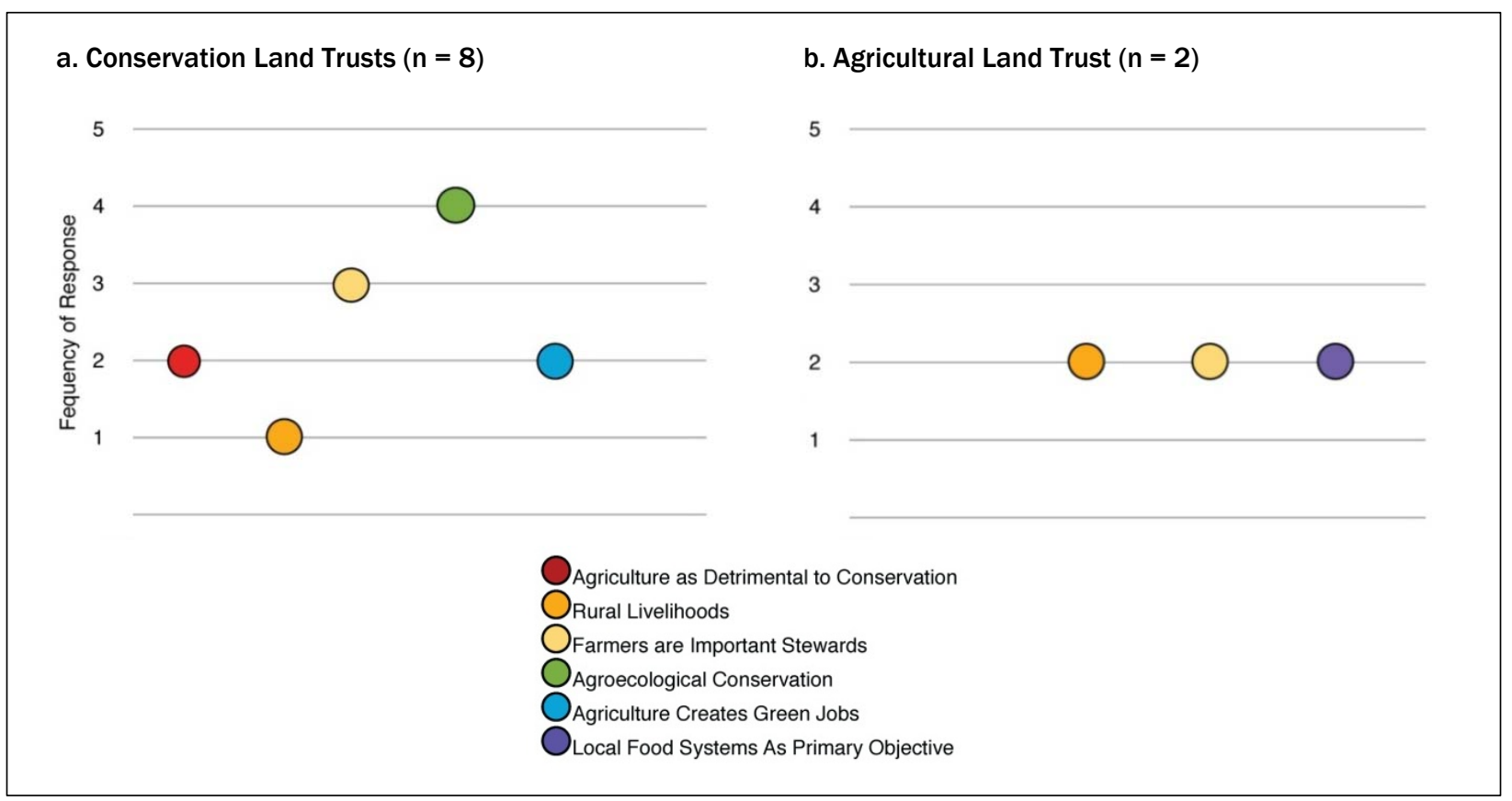

conservation land trust's staff felt so strongly about rural livelihoods and family farmers that they answered that both were central to their organization. This conservation land trust, though focused primarily on native habitat restoration, was proactively working with family ranches that had conservation easements on their farms in order to encourage conservation practices by ranching operations. ${ }^{14}$

Four conservation land trusts answered that agroecological conservation was important to their organization, and that they valued proactive agricultural management that achieved ecological conservation goals. The two conservation land trusts that spoke of green jobs had land that bordered and were headquartered on the urban periphery, and were referring to urban jobs in agriculture, rather than rural livelihoods. The agricultural land trusts were the only two organizations that spoke of the priority of local food systems as being central to conservation and to their mission. The staff of both spoke to the idea

14 This conservation land trust was not considered an agricultural land trust because in no way did the mission of the organization specify the preservation of agriculture. that environmentally responsible food production was more important than traditional natural resource conservation. As one might expect, the two agricultural land trusts went on to talk about the multiple benefits of agricultural agreements to their land trust, although both of these institutions stressed the need to integrate agriculture and conservation.

That conservation and agriculture need to be integrated was a views held by many of the land trust staff interviewed. Staff at Land Trust 2 (a conservation land trust) expressed that their land trust viewed "'working landscapes' as an essential part of conservation," and that their board strongly held that the best way to "get the environmental benefits [on the land is] when you've taken care of the first two parts of [the] sustainability [of the farmer], i.e., social and economic." This respondent continued: "Many of these people have been here for generations. We are just trying to make it possible for these people to continue to be viable and healthy as producers." This belief translates directly into the actions of that land trust. By the account of the land trust staff and local newspaper articles, this organization had stable, long-term relationships with experienced farmers and had 
started to collaborate successfully with several beginner farmer operations through one- to fiveyear leases. They were one of three conservation land trusts that directly identified the idea of effective conservation being directly dependent upon their relationships with farmers.

As represented on in the local food system category of figure 2, other land trusts described themselves as strictly agricultural preservation organizations. One executive director candidly confided that, "to be perfectly honest, [our] board is just really not that concerned with nature, the preservation of agriculture is the focus." The types of agriculture that this land trust supported was not relevant to their mission, as long as the farming was economically viable for the farmers. Thus, this land trust had little environmental restriction on the farming operations on their easement land, and, while speaking to the idea of the importance of local food production and the preservation of agricultural land for active farming, it did not engage in a critique of what could be considered environmental disregard by some types of farming operations. Here we witnessed a split between the two agricultural land trusts and within the local food system category. The other agricultural land trust was actively working to restrict destructive environmental practices of the farming operations using their land in order to uphold their tenets of conservation.

\section{Changing Orientations: Valuing the Role of Agriculture in Conservation?}

Although the spread of views was wide, exactly half of the conservation land trusts that took part in this study spoke to the fact that their organization was making more of an effort to be involved in agriculture. The interviews suggest that conservation-focused land trusts are in the process of identifying with the growing public discourse around local food. The valuation of these ideas likely arises from the growing food movement highlighted in the introduction. Land trust identification with this discourse came in a variety of forms. First, small blurbs about "working landscapes" and language around supporting family farms appear on their websites, and in speaking with their staff informally at the start of the research they noted interest in supporting more beginner farmers. Second, when setting up the interviews, many of the conservation land trusts would respond to the request to speak about their agricultural and beginner farmer policies with an answer along the lines of, "I'm so glad you called, we've been discussing this lately with our board and are definitely looking for guidance on the matter." These land trusts' staff stressed that they were interested in seeing the results of the study to further inform their development along these lines.

Third, land trusts of all kinds noted their commitments to agriculture and local food during the interviews. For example, one conservation land trust's manager stressed how committed they were by stating, "We are very focused on local. The way we reach out to people is local, healthy food." " An easement manager of an agricultural land trust said, along the same lines, "local food" was an important part of their position, specifying that, "we put it out there in our newsletter. We have a local production [and local foods] section of our newsletter. We have specific fundraising around that." These same two land trusts cumulatively manage approximately 70 percent of agricultural acreage of the sample population, and judging by their support base, how many agricultural acres they manage, and how many farmers they currently work with, both have been very successful in helping support farms through land access while simultaneously leveraging grant, foundation, and donor valuation of the local food systems discourse. Echoing the sentiment that land trusts benefit from their relationship with these farmers, one beginner farmer described that, as landlords, land trusts

are pretty straight forward, they don't require much, and they don't give much either... [but] we make them look really freakin' good. We make them look really good. They slap our name and face around [on their promotional materials], they have donor events

\footnotetext{
15 This land trust, although the stressed local food, was by it's mission a conservation land trust. Their mission emphasized the conservation of farmland, but not the preservation of an active farm economy.
} 
here, they have us to their little donor wing dings, wine and cheese events, we make them look really good. [Farmer 2, speaking of one of the land trusts interviewed]

But it was also evident that land trust staff held substantially different positions about the sincerity of land trusts' commitment to agriculture and local food systems. For example, when two personnel (who had varying levels of seniority) from the land trust that Farmer 2 is speaking of above were interviewed, the lower-level conservation land manager from that organization described that their land trust was only interested in conservation, not agriculture, even though they lease to farmers. This stood in stark contrast to a subsequent interview with an upper-management employee who described the values of the land trust as realizing the value of agriculture that works in harmony with conservation. In three cases in our research there was a similar disconnect in the pro-agriculture message of upper-management answers compared to the story told by either their staff or the farmers who worked with those land trusts. This suggests that there are some conservation land trusts that make false claims, or at least engage in stretching the truth, when it comes to their agricultural priorities. Supporting this disconnect between rhetoric and practice, a chief financial officer of a national land trust said of conservation land trusts that, "[My] guess is that 80 percent of the land trusts that tip to agriculture do so for landowner friendly fundraising."

There are several land trusts in coastal California that are developing, and indeed selling, this discourse of local food, and some may be doing so without aligning their internal practices with their publicly expressed sentiments. As expressed in the interviews, some of these land trusts still identify privately with a discourse of agriculture being detrimental to conservation. Beginning farmers reported experiencing first-hand the connection, or the disjunction, between land trusts' rhetoric and practice. We now turn to farmers' experiences to examine this.

\section{Beginner Farmers' Experiences with Land Trusts as Landlords and Land Managers}

[Land trusts] have really shaped what agriculture has looked like in a negative way. And that [means] there's less ranches, less farms, less family farmers that are able to live and work on the land. It seems like they just want all the people out. Want to drive along and not see any people, not see any houses. And that's just not what farming looks like.

- Farmer 3, long-time lease-holder with conservation land trust in the sample

The seven beginner farmers in the study sample were between 25 and 40 years of age, of White, Asian/White, Hispanic/White, and Hispanic backgrounds. There were four males and three females. Five had a bachelor's degree and one had a master's degree. Three had small farms of less than 10 acres (4 hectares). All these farmers were selling their goods through a mix of wholesale and direct marketing, two ran community supported agriculture (CSA) programs, and all of them sold at farmers' markets. Two of the operations were certified organic. All the farmers had created independent relationships with the land trusts, approaching the land trusts first about land they were interested in farming. In all of theses cases, the farmers were leasing from conservation land trusts.

All farmers interviewed were currently in oneto three-year lease arrangements with land trusts, renting land encumbered with conservation easements. Some of this land was owned fee simple by a third-party landowner, and other land was owned fee simple by land trusts themselves. While we initially believed that the conservation easements themselves would restrict farmers' ability to property manage the land (such as where a farmer could cultivate, or the ability of the operation to source water on their land) this was rarely the case. These farmers, all using agroecological methods, were not bothered by the restrictions imposed by the conservation easements' plans. In one case, however, the farmer would have liked to build a barn and was not able to within the easement restrictions.

While land trusts are attempting to figure out 
how to define their commitment to agriculture and local food, farmers who lease from conservation land trusts appear to be dealing with landlords who may not understand nor support them particularly well. The four farmers currently working with conservation land trusts reported frustrations including the short-term length of lease agreements, the land trusts' neglect of farm infrastructure, and their landlord leasing other farmland to agribusiness companies that clearly were not prioritizing conservation in terms of environmentally friendly agricultural practices. These complaints influenced whether the beginner farmers interviewed questioned the commitment of conservation land trusts to agriculture.

One unifying element of this dissatisfaction was that all the farmers feel that they are exalted when convenient for fundraising efforts and then subsequently ignored or mistreated. One rancher, who described being paraded about in a "dog and pony show" at donor events, described in the same breath that

the president has not even so much as come up and shooken our hands, when [they come] here, [they stay] in the vehicle. [They don't] even get out and say hello to us, [they don't] look us in the eye. But our millionaire friends, [they go] and [have] lunch with and talks about [their] plans. But to us it's totally secretive - we're blue collar. We're not going to give [them] any money, so we really don't matter is the feeling we get. [Farmer 3, long-time lease-holder with conservation land trust in the sample]

In the interviews, five of seven spoke of their frustration that land trusts in their area do not regularly advertise the availability of the land they manage that could potentially be used for agriculture. One rancher, who had met with several conservation land trusts in the Central Coast and was consistently denied leases on available land, exasperatedly commented that, "I've never ever seen a land trust put an RFP [request for proposal] out, ever. For a new contract, ever. If you find one, let me know. But as far as I can tell, they....all rent to large agribusiness companies." This lack of an open bidding process for access to land was disconcerting for beginning farmers who felt that their type of agriculture merged well with conservation.

Five of the seven farmers also expressed the sentiment that land trusts used the discourse of local food to get money and land from supporters, then turned around and leased that land to the highest agricultural bidder in order to subsidize their true interest: conservation of non-agricultural land. The same rancher who was concerned about land trusts renting to large agribusiness companies noted that in her experience in the Central Coast, she had heard many land trusts justify renting land trust land for conventional strawberry production because a company like "Driscoll's [a large-scale conventional and organic berry farming operation] has the capacity and the resources to really invest in this property and to do good conservation practices." Questioning how conventional strawberry production fits into the land trusts mission of conservation, the rancher commented,

No matter how you lay out those plastic beds, they are still plastic beds, right? Still cause erosion, and run off, and prevent the filtration of the water, and all that, and it's plasticulture, filling up all of our landfills and [expletive deleted]. So what's the [conservation] value in that? Well, they earn a lot of money, they probably get paid [US] $\$ 1,800$ 2,000 an acre, that's a big chunk of change. And they say they are using all of that money for stewardship of that property, so it's sustainable in that way - financially.

(Farmer 1, three year lease-holder with conservation land trust in the sample)

From the perspective of most of the beginner farmers interviewed, there was a noticeable gap between the values that land trusts communicate publicly and the lack of substantiation in their relationships with beginning farmers. All the farmers in this study expressed sentiments that land trusts in the area need to adapt to the changing public sentiment around conservation and agriculture to support local food systems. This led one farmer to question the valuation and support given to land 
trusts by the public. "I just wonder about the public value. I wonder about these taxpayer dollars for these properties." When this farmer asked staff of local land trusts how they justify that public money being spent, the staff replied, "Oh, it's to stem the tide, to prevent pavement," and her outraged response was, "Can we go further than that? OK guys, that's like the old story, prevent sprawl..." These responses suggest that beginning farmers felt that the kind of agriculture they practice is the kind now highly valued in public discourse, and warrants more support. Only one land trust acknowledged any need for public accountability in regard to its mission. Specifically, the interviewee mentioned that "for us to maintain our nonprofit status we have to serve the community that we're in." Yet, it is not entirely clear what kinds of priorities and practices are needed in the context of changing discourse around agriculture and conservation.

In short, the central tension identified in the farmer surveys is that the beginning farmers felt that if a land trust truly identifies with the discourse of local food and supports local food system development through its actions, the land trust should be very much supportive of the farmers in their rental agreements. But more often than not, Central Coast beginning farmers reported experiencing false pretense.

More research is needed to examine the extent to which the views of increased compatibility of environmental conservation and agriculture that conservation land trust staff discussed in the interviews are translated into these land trusts' actions. Indeed, there appear to be land trusts that are changing their rhetoric and practices, and others, as discussed by the farmers in our interviews, that have a rhetorical commitment to community food systems without much of a change in their practices. An additional explanation, which can refute or coexist with farmers' explanations of conservation land trusts using the discourse of local food to expand their real conservationwithout-people missions, is that many conservation land trusts are grappling with a new role: being landlords. All of the farmers interviewed had held leases with these land trusts for under 10 years at the time of interview, and these were among the first agricultural leases that any of these conser- vation land trusts had ever managed. The agribusiness Driscoll's that one beginner farmer complained about was leasing substantially more land and had worked with that land trust for many years. This example leads us to believe it is possible that over many years the frictions inherent in a landlord-tenant relationship could be worked out. Thus in addition to questions of intent, there are questions about whether conservation land trusts currently have the expertise to adequately supervise agricultural leases, and about the kinds of learning and resources that would be useful for better accommodating farmer tenants. Of course, learning to become better landlords requires a genuine intent to support beginning farmers, which for many of the farmers interviewed appears to be lacking. But there remains the possibility that in time conservation land trusts could become open to new priorities and could learn how to better blend their conservation values with the genuine and effective support of beginning farmers.

\section{Conclusion}

In this paper we examined how land trusts in coastal California identify with conservation and agriculture by focusing on the key elements of, and tensions in, their current relationships with beginner farmers. We found that conservation land trusts' identities in particular appear to be adapting to changing discourses around nature, food, and conservation. Some conservation land trusts have taken the popular food movement as a cue to engage newly emerging agricultural forms, and are adapting by shifting their board membership, mission statements, and, in some cases, practices to meet and support that transition. Yet some land trust staff members and beginning farmers also noted instances in which conservation land trusts publicly state their support for beginner farmers and the creation of local food systems to capture more resources for their conservation missions, yet do not follow through on their support of beginner farmers. Beginner farmers interviewed report feeling taken advantage of in these relationships.

We want to conclude on two main points. First, there appears to be a great deal of potential for land trusts to connect a new swath of the public to conservation through agriculture and the food 
system, but making these connections work well for everyone appears challenging. Several of the land trusts noted in the interviews that their organizations were struggling with how to stay relevant and financially viable in an increasingly urbanized nation, where much of the population does not live in a location where intimate connection with the natural world is possible. To maintain the conservation movement in this context, figuring out how to connect with urban populations will likely be important. A recent Time magazine article entitled "Foodies Can Eclipse (and Save) the Green Movement" noted the possibility that if the local food movement "continues to grow it may be able to create just the sort of political and social transformation that environmentalists have failed to achieve in recent years" (Walsh, 2011, para. 2. This echoes a long-standing argument made by academics about the importance of merging conservation, livelihoods, and agriculture (e.g., Zimmerer, 2006). The food movement and its proponents have been relatively successful at connecting an urban population with environmental issues. By making environmental issues relevant and personal, the food movement has had some success in putting environmental issues and environmental politics on the proverbial American table. This connects with Souder and Fairfax's (2000) argument that the public should take a greater interest in the management philosophies of land trusts. It is only through democratic processes that that the public can re-engage fully with public goods held in trust, to make sure that the publically sanctioned tools that exist (such as conservation easements) genuinely benefit public interests. In order for land trusts to truly represent and follow popular consciousness and understanding, there needs to be more public dialogue around land use policies and the role of land trusts in managing public goods. It is important to hear through public forums about the desired connections between conservation land trusts and the local food movement.

Authentically connecting to the local food movement, and beginner farmers as a subset of it, offers potential for land trusts to reconnect with the historical national sentiment of populist agricultural preservation, and to connect with a new generation of American foodies. Though limited in scope and scale, our study identifies some of the potential difficulties of these new relationships, especially around land trusts as landlords. While there is much potential for benefits on both sides, both parties should be cautious when approaching access to land through these arrangements. We believe that for a positive outcome, it is critical that the parties involved have frank discussion about their own values and goals, and identify shared interests that can be focused on.

Our last point is around whether the large numbers of beginner farmers will succeed in creating the next generation of farmers. Innovation in land access will be critical if beginner farmers are to enter the agricultural sector and reverse the trend of increasing average farmer age. Land trusts can be a key part of increasing access, but the 145 million acres $(58,679,400$ hectares) of land in their care is small relative to the one billion acres (404,685,644 hectares) that are currently in active cultivation and ranching in the US today (USDA, 2013), and the structural ills of American agrarian capitalism are far deeper and broader than access to land offered by land trusts. Thus it is likely that beginner farmers will need to figure out how to access more land than what land trusts can currently offer. To do so they will need policy support that is broader than what land trusts can achieve individually, and even collectively. Progressive policies that hold promise include Nebraska's Initiative 300, which altered Nebraska's constitution to ensure that no corporation can hold a title on real estate used for farming or ranching, and the recently passed California legislation (AN 551) that lowers property taxes on urban properties if the owners dedicate them to growing food for at least five years (Romney, 2013).

But we also know that land access is a piece in a much larger puzzle. Success will rest in part around the economic success of beginner farmers in agricultural and local food system endeavors, and such success is not a given (Galt, 2013). Though it is impossible to say what will happen on the national scale from our small sample of farmers, for the sake of closure we note what has happened to the beginner farmers interviewed in 2010. Two of the farmers are still farming with the same land 
trusts on the same pieces of land, and one of those farmers now rents substantially more land trust land for his or her operation. Two other farmers have expanded production and are still farming in the same locales, but neither now farms on land trust land, due to a number of reasons that include cost, insecure and short-term tenure, and the advantage of other (private) landlords' knowledge and experience in working with agricultural lessees. Three of the farmers have stopped farming in the Central Coast of California by moving out of state where land prices are cheaper and there is less competition in the local food markets (of these, one has become an agricultural professional, working a desk job and supporting her husband's small ranching operation with an off-farm income). Remarkably, given the changing nature of many small and beginning businesses, all of these beginner farmers are still involved in farming in a substantial way. We recommend and look forward to further research into the long-term sustainability of this population of farmers who are staying in agriculture and making their social and environmental visions a reality.

We believe that while supporting beginner farmers is not the silver bullet to reverse the depopulation of the rural landscape that has occurred over the last many decades, it does speak to the hope for an agrarian revival, one that appears to be growing from the grassroots and has the potential to be supported structurally by innovative policies. From our sample (and from long-term evaluations such as that of Perez et al., 2010) it is clear that even when beginner farmers do not decide to be farmers as their main livelihood strategy, most stay in the agricultural field and are involved in some sort of agricultural production. Thus, support of beginner farmers in a multitude of forms matters, because the more folks at the table discussing the future of the American agricultural landscape, the better.

\section{Acknowledgments}

We would like to acknowledge the farmers, advocates, and land trusts that participated in this study. As always, we appreciate our respective spouses, Damian Parr and Eve Hightower, for their continual support of our work. We'd also like to thank Reggie Knox,
Mark Lipson, Darryl Wong, Deborah Giraud, Brett Malone, Kendra Johnson, Tracy Lerman, Ildi CarlisleCummins, Jan Perez, Michael Weaver, Daniel Press, Al Sokolow, Heidi Ballard, Luis Guarnizo, and Jered Lawson for their input on research topics and subsequent drafts of the paper as well as the outstanding Galt Lab for their excellent feedback and stellar cheerleading.

\section{References}

Ahearn, M., \& Newton, D. (2009). Beginning farmers and ranchers (Economic Information Bulletin No. 5). Washington, D.C.: USDA, Economic Research Service. Retrieved from http://www.ers.usda.gov

Allen, R., \& Harris, G. (2005, February). What we know about the demographics of U.S. farm operators. Presentation at the USDA National Agricultural Statistics Service Agricultural Outlook Forum, Washington, D.C.

Baker, J. R., Duffy, M. D., \& Lamberti, A. (2004). Farm succession in Iowa. Ames, Iowa: Iowa State Extension Center, Beginning Farmer Center. Retrieved from: http://www.csrees.usda.gov/nea/economics/fsll/ publications/iowa.pdf

Baume, M. (2012, April 12). Urban farmers expect bumper crop. NBC Bay Area. Retrieved from http://www.nbcbayarea.com/news/green/UrbanFarmers-Expect-Bumper-Crop-120401714.html

Berry, W. (1977). The unsettling of America: Culture and agriculture. San Francisco: Sierra Club Books.

Berry, W. (1995). Another turn of the crank: Essays. Washington, D.C.: Counterpoint.

Bradbury, Z. I., von Tscharner Fleming, S., \& Manalo, P. (Eds.). (2012). Greenhorns: 50 dispatches from the new famers' movement. North Adams, Massachusetts: Storey Publishing.

Brewer, R. (2003). Conservancy: The land trust movement in America. Lebanon, New Hampshire: University Press of New England.

Brillinger, R., Merrill, J., \& Lyddan, K. (2013). Triple harvest: Farmland conservation for climate protection, smart growth and food security in California. California Climate and Agriculture Network. Retrieved from http://calclimateag.org/triple-harvest/

Buland, D. (2010). Limited resource farmer and rancher (LRF/R): Beginning farmer program definition (webpage). Washington, D.C.: USDA Natural Resources Conservation Service. Retrieved from http://www. lrftool.sc.egov.usda.gov/BFRP_Definition.aspx 
Burros, M. (2009, March 20). Obamas to plant vegetable garden at White House. New York Times, p. A1.

California Council of Land Trusts. (2010). Home page. Retrieved Aug. 27, 2013, from http://www.calandtrusts.org/index.cfm

Chicoine, D. L. (1981). Farmland values at the urban fringe: An analysis of sale prices. Land Economics, 57(3), 353-362. http://dx.doi.org/10.2307/3146016

Coppock, D., \& Ames, L. (1989). Evaluation of agricultural land trusts pursuant to Government Code Section 51297.5. [Sacramento, California?]: California State Coastal Conservancy.

Corbin, J., \& Strauss, A. (1990). Grounded theory research: Procedures, canons, and evaluative criteria. Qualitative Sociology, 13(1), 3-21. http://dx.doi.org/10.1007/BF00988593

Dimitri, C., Effland, A., \& Conklin, N. (2005). The 20th century transformation of U.S. agriculture and farm policy (Economic Information Bulletin No. 3). Washington, D.C.: USDA, Economic Research Service. Retrieved from http://www.ers.usda.gov/publications/

Endicott, E. (Ed.). (1993). Land conservation through public/private partnerships. Washington, D.C.: Island Press.

Environmental Protection Agency (EPA). (2011). Ag 101: Demographics (webpage). Washington, DC: EPA. Retrieved from http://www.epa.gov/agriculture/ ag101/demographics.html

Galt, R. E. (2013). The moral economy is a doubleedged sword: Explaining farmers' earnings and selfexploitation in community supported agriculture. Economic Geography, 89(4), 341-365. http://dx.doi.org/10.1111/ecge.12015

Galt, R. E., Clark, S. F., \& Parr, D. (2012). Engaging values in sustainable agriculture and food systems education: Toward an explicitly values-based pedagogical approach. Journal of Agriculture, Food Systems, and Community Development, 2(3), 43-54. http://dx.doi.org/10.5304/jafscd.2012.023.006

Gardner, B. L. (1974). Farm population decline and the income of rural families. American Journal of Agricultural Economics, 56(3), 600-606. http://dx.doi.org/10.2307/1238614

Gillespie, G. W., Jr., \& Johnson, S. E. (2010). Success in farm start-ups in the northeastern United States.
Journal of Agriculture, Food Systems, and Community Development, 1(1), 31-48. http://dx.doi.org/10.5304/jafscd.2010.011.008

Greene, C., Dimitri, C., Lin, B.-W., McBride, W., Oberholtzer, L., \& Smith, T. A. (2009). Emerging issues in the U.S. organic industry (Economic Information Bulletin No. 55). Washington, D.C.: USDA, Economic Research Service. Retrieved from http://www.ers.usda.gov/publications/

Grobe, K. (2009, July 18). Dominican Hospital garden supplies cafeteria with organics. Santa Cruz Sentinel. Retrieved from http://www.santacruzsentinel.com/ci 12865178

Guthman, J. (2004). Agrarian dreams: The paradox of organic farming in California. Berkeley, California: University of California Press.

Jacobsen, K. L., Niewolny, K. L., Schroeder-Moreno, M. S., Van Horn, M., Harmon, A. H., Chen Fanslow, Y. H.,...Parr, D. (2012). Sustainable agriculture undergraduate degree programs: A land-grant university mission. Journal of Agriculture, Food Systems, and Community Development, 2(3), 13-26. http://dx.doi.org/10.5304/jafscd.2012.023.004

Johnson, C. D. (1990). A bistorical look at farm income (Statistical Bulletin No. 154702). Washington, D.C.: U.S. Dept. of Agriculture, Economic Research Service.

Johnson, K. (2008). Conserving farmland, but for whom? (Unpublished master's thesis). University of California, Davis, California.

Kingsolver, B. (2007). Animal, vegetable, miracle: A year of food life. New York: Harper Collins.

Kirschenmann, F. (2009, Winter). Rethinking the politics of food. Leopold Letter [Leopold Center for Sustainable Agriculture]. Retrieved from http://www.leopold.iastate.edu/news/leopoldletter/2009/winter/kirschenmann-rethinkingpolitics-food

Levins, R. A. (2000). The food system: A holistic policy approach (Staff Paper P00-4). Minneapolis, Minnesota: Department of Applied Economics, University of Minnesota.

Livanis, G., Moss, C. B., \& Breneman, V. E. (2006). Urban sprawl and farmland prices. American Journal of Agricultural Economics, 88(4), 915-929. http://dx.doi.org/10.1111/j.1467-8276.2006. 00906.x 
Lyson, T. (2004). Civic agriculture: Reconnecting farm, food, and community. Medford, Massachusetts: Tufts University Press.

Martinez, S., Hand, M. S., De Pra, M., Pollack, S., Ralston, K., Smith., T.,...Newman, C. (2010). Local food systems: Concepts, impacts, and issues (Economic Research Service Report No. ERR-97). Washington, D.C.: USDA, Economic Research Service.

Retrieved from http://www.ers.usda.gov/publications/

Merenlender, A. M., Huntsinger, L., Guthey, G., \& Fairfax, S. K. (2004). Land trusts and conservation easements: Who is conserving what for whom? Conservation Biology, 18(1), 65-76. http://dx.doi.org/ 10.1111/j.1523-1739.2004.00401.x

Meter, K. (2012). How do we grow new farmers? Learning from another American pastime. Journal of Agriculture, Food Systems, and Community Development, 2(2), 3-6. http://dx.doi.org/10.5304/jafscd.2012.022.015

Morris, A. W. (2008). Easing conservation? Conservation easements, public accountability and neoliberalism. Geoforum, 39(3), 1215-1227. http://dx.doi.org/10.1016/i.geoforum.2006.10.004

Peck, J., \& Tickell, A. (2002). Neoliberalizing space. Antipode, 34(3), 380-404.

http://dx.doi.org/10.1111/1467-8330.00247

Perez, J., Parr, D., \& Beckett, L. (2010). Achieving program goals? An evaluation of two decades of the Apprenticeship in Ecological Horticulture at the University of California, Santa Cruz. Journal of Agriculture, Food Systems, and Community Development, 1(1), 107-124. http://dx.doi.org/10.5304/jafscd.2010.011.012

Pollan, M. (2006). The omnivore's dilemma: A natural history of four meals. New York: Penguin.

Raftery, I. (2011, March 6). In new food culture, a young generation of farmers emerges. New York Times, p. A19. Retrieved from http://www.nytimes.com/ 2011/03/06/us/06farmers.html

Romney, L. (2013, October 2). New California law aims to cultivate urban agriculture. Los Angeles Times. Retrieved from http://articles.latimes.com/2013/ oct/02/local/la-me-urban-agriculture-law20131003

Salamon L. M. (2002). The new governance and the tools of public action. In L.M. Salamon (Ed.), The tools of government: A guide to the new governance. (pp. 147). New York: Oxford University Press.
Souder, J., \& Fairfax, S. (2000). In lands we trusted: State trust lands as an alternative theory of public land ownership. In C. Geisler \& G. Daneker (Eds.), Property and values: Alternatives to public and private ownership (pp. 87-118). Washington, D.C.: Island Press.

Spencer, K., \& Kaplan, A. (2010). Students restoring waterways: Protecting Monterey Bay habitats. Agrarian Advocate [Community Alliance with Family Farmers], Spring, 6. Retrieved from http://caff.org/wp-content/uploads/2010/07/ AgAd spring2010.pdf

Stern, A., \& Nochi, K. (2009, February 13). New crop of farmers. Yes Magazine. Retrieved from http://www.yesmagazine.org/issues/food-foreveryone/new-crop-of-farmers

Thompson, E., Jr. (2009). California agricultural land loss \& conservation: The basic facts. American Farmland Trust. Retrieved from http://www.farmland.org/documents/AFT-CAAgricultural-Land-Loss-Basic-Facts 11-23-09.pdf

Unger, S., \& Lyddan, K. (2011). Sustaining our agricultural bounty: An assessment of the current state of farming and ranching in the San Francisco Bay Area. Joint publication of American Farmland Trust, Greenbelt Alliance, and Sustainable Agriculture Education. Retrieved from http://www.farmland.org/ documents/SustainingourAgriculturalBounty.pdf

United States Department of Agriculture [USDA], National Agricultural Statistics Service. (2013). Farms, land in farms, and livestock operations 2012 summary. Washington, D.C.: USDA. Retrieved from http://usda01.library.cornell.edu/usda/ current/FarmLandIn/FarmLandIn-02-19-2013.pdf

USDA, National Institute of Food and Agriculture. (2010). Beginning Farmers and Ranchers Development Program (webpage). Retrieved from http://www.nifa.usda.gov/fo/beginningfarmerand rancher.cfm

Walsh, B. (2011, February 15). Foodies can eclipse (and save) the green movement. Time. Retrieved from http://www.time.com/time/health/article/ $\underline{0,8599,2049255,00 \cdot \mathrm{html}}$

Zimmerer, K. S. (2006). Geographical perspectives on globalization and environmental issues: The innerconnections of conservation, agriculture, and livelihoods. In K. S. Zimmerer (Ed.), Globalization and new geographies of conservation (pp. 1-43). Chicago: University of Chicago Press. 